\title{
Predicting outgrowth and inactivation of Clostridium perfringens in meat products during low temperature long time heat treatment
}

Duan, Zhi; Holst Hansen, Terese ; Hansen, Tina Beck; Dalgaard, Paw; Knøchel, Susanne

Publication date:

2013

Document Version

Publisher's PDF, also known as Version of record

Link back to DTU Orbit

Citation (APA):

Duan, Z., Holst Hansen, T., Hansen, T. B., Dalgaard, P., \& Knøchel, S. (2013). Predicting outgrowth and inactivation of Clostridium perfringens in meat products during low temperature long time heat treatment. Abstract from 8th International Conference on Predictive Modelling in Food, Paris, France.

\section{General rights}

Copyright and moral rights for the publications made accessible in the public portal are retained by the authors and/or other copyright owners and it is a condition of accessing publications that users recognise and abide by the legal requirements associated with these rights.

- Users may download and print one copy of any publication from the public portal for the purpose of private study or research.

- You may not further distribute the material or use it for any profit-making activity or commercial gain

- You may freely distribute the URL identifying the publication in the public portal 


\section{Predicting outgrowth and inactivation of Clostridium perfringens in meat products during low temperature long time heat treatment}

$\underline{\text { Zhi Duan }}^{1,2}$, Terese Holst Hansen ${ }^{2}$, Tina Beck Hansen ${ }^{3}$, Paw Dalgaard ${ }^{1}$, Susanne Knøchel ${ }^{2}$

${ }^{1}$ Division of Industrial Food Research, National Food Institute, Technical University of Denmark, Søltofts Plads, Building 221, DK-2800 Kgs. Lyngby, Denmark

${ }^{2}$ Department of Food Science, University of Copenhagen, Rolighedsvej 30, DK-1958 Frederiksberg

C, Denmark

${ }^{3}$ Division of Food Microbiology, National Food Institute, Technical University of Denmark, Mørkhøj Bygade 19, DK-2860 Søborg, Denmark

\section{OBJECTIVE}

Sous-vide cooking and molecular gastronomy has started a wave of experimenting with Low Temperature Long Time (LTLT) heat treatments. Heat treatments, at temperatures as low as $50^{\circ} \mathrm{C}$, have been suggested by celebrity chefs. LTLT treatments often take hours to reach to the final core temperature and $\mathrm{Cl}$. perfringens is, therefore, of special interest as it may outgrow during the coming up time and cause food safety problems. This study was undertaken to set up a predictive tool to establish the outgrowth potential of $C$. perfringens in LTLT meat products as a function of the applied heating profile.

\section{METHODS}

Challenge tests were performed at two dynamic temperature profiles (fast LTLT, $2.6 \mathrm{~h}$ from 10 to $53^{\circ} \mathrm{C}$, and slow LTLT, $3.8 \mathrm{~h}$ from 10 to $53^{\circ} \mathrm{C}$ ) with three types of inoculums (spores, heat-active spores and vegetative cells) of Cl. perfringens 790-94 in two different types of meat pork (pH 5.6) and chicken ( $\mathrm{pH}$ adjusted to 6.8). Challenge tests representing LTLT treatments of beef were collected from the literature. The obtained growth data were used for evaluation of three different growth models originally validated for prediction of growth during cooling (Le Marc et al. 2008, Juneja et al. 2011, Jaloustre et al. 2011). The data in inactivation phase were used for evaluation of three inactivation models generated by Foegeding and Busta (1980), van Asselt and Zwietering (2006) and Jaloustre et al. (2012). Finally, a new growth model, derived from the model structure of Le Marc et al. (2008), was developed from literature data (215 isothermal growth data), and was combined with a linear inactivation model developed from data at $53^{\circ} \mathrm{C}$ from this study for completely predicting fate of $C l$. perfringens during LTLT treatment.

\section{RESULTS}

Very short lag times were observed in most of the challenge tests, especially in high pH chicken. By using the acceptable prediction zone method, performance of literature models was evaluated and none of the growth and inactivation models could successfully predict the growth or inactivation of $\mathrm{Cl}$. perfringens for the LTLT conditions of our challenge tests. Therefore, a new growth model and a new 
inactivation model were developed and combined to predict the overall fate of $\mathrm{Cl}$. Perfringens during LTLT profiles at $53^{\circ} \mathrm{C}$. However, predicted lag time was still much longer than the observed lag time in our challenge tests, which caused a general underestimation of growth giving rise to overestimation of inactivation in particular for chicken. To obtain more precise predictions, an RLT of 2-3 was recommended for chicken, independent on type of inoculums, and for vegetative cells in pork. For spores and heated spores in pork the increase of $\mathrm{Cl}$. perfringens during LTLT coming up time never exceeded $1 \log _{10}$-unit.

\section{CONCLUSIONS AND IMPACT OF THE STUDY}

A model combining both growth as well as inactivation for prediction of fate of $\mathrm{Cl}$. perfringens during the LTLT treatment was developed. The model is the first predictive model specifically designed for LTLT treatment of meats. Very short lag times were observed during LTLT treatments, which were not observed in isothermal or cooling conditions previously. The reason for short lag time during slowly increasing temperature conditions, and how to predict it, should be interesting for future studies.

\section{REFERENCES}

Foegeding et al., 1980, Journal of Food Science, v. 45, no. 4.

Jaloustre et al., 2011, Food Microbiology, v. 28, no. 2.

Jaloustre et al., 2012, International Journal of Food Microbiology, v. 154, no. 1-2.

Juneja et al., 2011, Food Microbiology, v. 28, no. 4.

Le Marc et al., 2008, International Journal of Food Microbiology, v. 128, no. 1.

van Asselt et al., 2006, International Journal of Food Microbiology, v. 107, no. 1. 